\title{
The Professional Profile and the Physical Therapy Service in the Emergency Units in the State of São Paulo
}

\author{
Mariel P. Oliveira Junior ${ }^{1 *}$, Caroline C. Silva ${ }^{2}$, Sabrina M. Cunha ${ }^{2}$, Augusto G. T. Cruz ${ }^{2}$, \\ Paulo E. J. Campos², Gabriel G. Maia ${ }^{3}$, Leandro M. Azeredo4, Marcus V. M. Pinto5, Eliza C. Macedo6
}

${ }^{1}$ Master Student in Health and Technology in the Hospital Space, Federal University of the State of Rio de Janeiro (UNIRIO), Bezerra de Araújo College (FABA), Rio de Janeiro, Brazil

${ }^{2}$ Post-Graduate Course in Hospital Physiotherapy at Delta College, IAPES and Physiotherapy Campos, Campinas, Brazil ${ }^{3}$ Physiotherapist at the State University of Rio de Janeiro (UERJ), Rio de Janeiro, Brazil ${ }^{4}$ Physiotherapist at the Military Police Hospital in Rio de Janeiro, Rio de Janeiro, Brazil ${ }^{5}$ Researcher and Clinician at the Celulare Institute (INSTCELULARE), Petrópolis, Brazil ${ }^{6}$ Federal University of the State of Rio de Janeiro (UNIRIO), Rio de Janeiro, Brazil Email: *marieljunior@yahoo.com.br

How to cite this paper: Oliveira Junior, M.P., Silva, C.C., Cunha, S.M., Cruz, A.G.T., Campos, P.E.J., Maia, G.G., Azeredo, L.M., Pinto, M.V.M. and Macedo, E.C. (2021) The Professional Profile and the Physical Therapy Service in the Emergency Units in the State of São Paulo. Open Journal of Emergency Medicine, 9, 150-161. https://doi.org/10.4236/ojem.2021.94015

Received: August 27, 2021

Accepted: October 17, 2021

Published: October 20, 2021

Copyright $\odot 2021$ by author(s) and Scientific Research Publishing Inc. This work is licensed under the Creative Commons Attribution International License (CC BY 4.0).

http://creativecommons.org/licenses/by/4.0/

\section{Open Access}

\begin{abstract}
The emergency room is the entrance door of hospitals for patients who are in risk of life, and the role of the physiotherapist in this area is recognized as a qualified member of the team, helping to reduce the rate and time of orotracheal intubation, judicious use of invasive mechanical ventilation (MV) and non-invasive ventilation (NIV). The objective was to know the profile and performance of physical therapists in the emergency departments of hospitals in the state of São Paulo. Conducted through a semi-structured questionnaire covering personal and professional aspects, and analyzed and described in percentage form. Thirty-six questionnaires were analyzed, and it was observed that $92 \%$ provide emergency care, but only $25 \%$ work exclusively. Among the main reasons for admission to this sector are: acute respiratory failure (44\%) and decreased level of consciousness (36.1\%). Regarding the physiotherapeutic resources used in the emergency department, $97.2 \%$ make use of NIV, followed by monitoring of MV parameters (94.4\%) and modification of parameters (94.4\%). We also found that the average time of MV in this sector is 3 to 21 days (50\%), and that $33 \%$ believe there is delay between indication and installation of NIV. The physiotherapist has much to contribute in emergency units, however, he must be trained through the search for technical and scientific knowledge, thus contributing to the consolidation of this area of expertise.
\end{abstract}




\section{Keywords}

Emergencies, Physiotherapy, Professional Practice Area

\section{Introduction}

Urgent and emergency care (UE) is the gateway to hospitals for patients who present physical and biological alterations, thus risking their lives [1]. These services integrate the hospital sectors marked by unpredictability, carrying out actions with the purpose of improving the quality of the care provided and preserving life [2].

The emergency activity is regulated by the Ministry of Health, according to the ordinance No. 824 of June 24, 1999 and should be constituted in all sectors such as intensive care [3]. Regarding the legal issues that govern the exercise in the UE, the ordinance no. 2048/2002 of the Ministry of Health stands out, where physiotherapy is cited as a support service, clinical follow-up, establishing the need for it in the emergency room according to demand and hospital need [4]; already the ordinance 1601/2011 of the Ministry of Health established guidelines for the implementation of Emergency Care Units (ECUs) and the set of 24-hour emergency services, in accordance with the National Policy for Emergency Care, so that these units must have an interdisciplinary multidisciplinary team compatible with their size [5].

The insertion of physiotherapy in the emergency room in Brazilian hospitals is recent. Used in a wide range of acute situations, physical therapy has already demonstrated advantages that reflect faster and more efficient care, lower rates and time of orotracheal intubation, judicious use of invasive and noninvasive mechanical ventilation as well as reduced adverse effects and mortality linked to indiscriminate use, fewer complications and hospital stay. Aiming to prevent the patient's clinical condition from worsening, the physiotherapist acts with the main objective of fast and efficient support in cardiorespiratory dysfunctions [6].

\section{Answering the First Question}

Respiratory and cardiovascular physiotherapists have been requested in hospital emergency rooms to evaluate and treat patients with acute respiratory failure, offering their services through the use of noninvasive mechanical ventilation and/or the therapeutic use of oxygen, contributing to the management of invasive mechanical ventilation and also in favoring its weaning, With these attributions, it becomes possible to treat respiratory failure and prevent ventilator-associated complications in subgroups of patients in whom clinical experience and scientific evidence have demonstrated important results in the treatment of atelectasis, acute cardiogenic pulmonary edema (ACPE), and exacerbated chronic obstructive pulmonary disease (COPD) [7].

In 2015, the American Heart Association (AHA) cited for the first time the inclusion of the physical therapist as part of the multidisciplinary team of the 
rapid response team, aiming to prevent in-hospital cardiac arrest [8]. The lack of recognition as a specific area of knowledge and specialty of the physiotherapist may be one of the factors responsible for the lack of training, continuing education and full performance [9].

The ECU's are non-hospital units of care to the UE, with the operation without interruption, having the multiprofessional body that includes In 2015, the American Heart Association (AHA) cited for the first time the inclusion of the physiotherapist as part of the multidisciplinary team of the rapid response team, aiming to prevent in-hospital cardiac arrest [8], this fact makes it more important that the physiotherapist has a specific formation and training for this practice. The non-recognition as a specific area of knowledge and specialty of the physiotherapist may be one of the factors responsible for the lack of training, continued education and full practice by physicians and nurses, and according to the demand of local patients, however, there is no presence of the physiotherapist in this area, which reinforces the need for this professional [10].

\section{Answering the Third Question}

Considering the recent international recognition by the American Heart Association (AHA), in 2015, the creation of the physical therapist practice area in the Emergency Room in Brazil was recently approved by resolution COFFITO 509 published in 2019, where the Federal Council of Physical Therapy and Occupational Therapy recognizes the performance of this professional in this environment, considering that the physical therapist is a member of health care teams in various hospital sectors such as: Intensive Care Units-UTIs, Emergencies, Emergency Room, Emergency Room and other sectors acting in the use of invasive mechanical ventilation, oxygen therapy and non-invasive mechanical ventilation, being necessary and recommended that such professionals trained in basic life support (BLS), advanced cardiovascular life support in adults (ACLS), or similar training course in life support to the critically ill patient [11].

\section{Justification}

This study is relevant because of the scarcity of this theme and how much it can contribute to the development of the area to be addressed. It is important to realize how impactful this may be through the results that may be presented, contributing to a possible orientation and reformulation of physical therapy services in emergency rooms, considering the investments accessible to managers of the very ones that will be presented.

External difficulties such as the insufficiency of the basic network, the lack of vacancies for hospitalization and for complex exams, the lack of harmony with the pre-hospital care, and the unavailability of specialized outpatient clinics, are factors that create specialized opportunities for the performance of the physiotherapist [12]. 
The performance of physical therapy in the emergency room requires more research, due to the lack of research in this scenario, and the presence of physical therapists in this environment [13].

\section{Objectives}

This study aimed to understand the profile of this professional, as well as to identify the existence of hospital emergency services and the participation of physical therapy in the state of São Paulo.

Regarding the specific objectives, it investigated the existence of hospital emergency services with the participation of physical therapy, collected data related to the management, autonomy and work format of this professional in the sector and interpreted the repercussions and outcomes related to physical therapy.

\section{Methodology}

An observational and retrospective study was carried out, with a quantitative approach.

In an observational study, the researcher is intended to be an observer, and may only act as an individual who will analyze the data or take some measurements during a time of collecting the variables involved. Observational studies present a great contribution for looking at events of interest [14]. The retrospective study will investigate that the process being investigated has already occurred, and that some causal factors may precede an outcome [15].

The study included 36 physical therapy professionals who work in hospitals where emergency services are present in the state of São Paulo.

The heads of the physical therapy services of places that had emergencies were contacted, and thus we had contact with the professionals. The individuals who agreed to participate received an initial explanation via email about the study objectives, and signed the Free and Informed Consent Term indexed in Google Drive, and then had access to answer a semi-structured questionnaire composed of 12 questions.

Professionals who do not work in hospitals or ECU's were excluded from the research. The questionnaire contained 12 questions, divided into five domains: Sociodemographic characteristics of the physical therapists, characteristics of the physical therapy service, profile of the patients admitted, physical therapy resources used by the professionals, and characteristics of the ventilatory support.

The data of this study were described in Microsoft ${ }^{\oplus}$ Office Excel, and analyzed by the program $\mathrm{R}$ with the presentation of graphs and tables.

\section{Theoretical Assumptions}

Physiotherapy, which, by conceptual aspects, appeared as a profession exclusively rehabilitator of sequelae, evolves if including the process of restructuring health models in which the integral attention and the humanization of care are 
precepts considered fundamental to health care. Nowadays, the continuous presence of the physiotherapist in the emergency room has not yet been officially regulated and the benefits that are being achieved with the performance of these professionals, who can contribute to the work of other members of the multidisciplinary team for a better outcome in the patient's condition, are already being discussed [16].

Due to the absence of the physiotherapist and the lack of knowledge on the part of the members of the emergency unit, the real function of the physiotherapist inside the UEs seemed to be a great barrier for the performance of this professional, which was motivated in a contrary way when the physiotherapist started to enter these units in countries like Australia and United Kingdom, making the work more contributive and resolute in these sectors. Respiratory and cardiovascular physiotherapists and intensive care specialists are frequently requested in hospital emergency units or emergency rooms to evaluate and treat patients with acute respiratory failure using noninvasive mechanical ventilation and/or the therapeutic use of oxygen, to collaborate in the management of invasive mechanical ventilation, and to facilitate its weaning when it is impossible to transfer these patients to the ICU [17].

\section{Results and Discussions}

\section{Answering the Second Question}

Thirty-six questionnaires were answered and analyzed in different cities of the state of São Paulo, with $36 \%$ of the respondents $(\mathrm{n}=13$ ) being male and $64 \%$ ( $\mathrm{n}$ $=23$ ) female (Figure 1). Of these, $8 \%(n=3)$ of the participants were between 20 - 25 years old, $36 \%(n=13)$ between 25 - 30 years old, $27 \%(n=10)$ between 30 35 years old and $27 \%(\mathrm{n}=10)$ between 35 - 40 years old. The time of training of the professionals analyzed was $42 \%(n=15)$ from 1 to 5 years, $22 \%(n=8)$ of them with training from 6 to 10 years, $31 \%(\mathrm{n}=11)$ from 11 to 16 years, and only $3 \%(\mathrm{n}=1)$ of the respondents with more than 16 years. In what was presented about the academic background, $78 \%(\mathrm{n}=28)$ have a specialization as their highest academic degree, $11 \%(n=4)$ have only an undergraduate degree, $6 \%(n=2)$ have a master's degree, $3 \%(n=1)$ have an MBA and Management

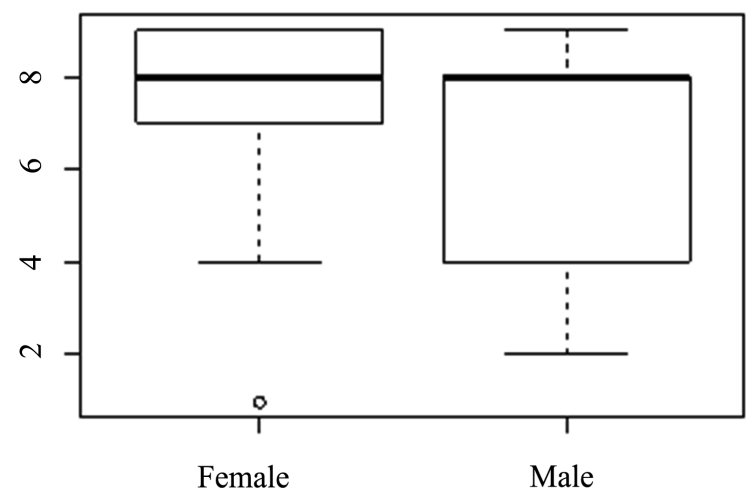

Figure 1. Gender of the coordinator of physical therapy in the emergency department. 
degree, and 3\% ( $\mathrm{n}=1)$ have a doctorate. Regarding the type of unit these professionals work in, $42 \%(\mathrm{n}=15)$ work in private institutions, $36 \%(\mathrm{n}=13)$ work in municipal public institutions, $14 \%(\mathrm{n}=5)$ work in state public institutions, $6 \%$ $(\mathrm{n}=2)$ in university institutions, and $3 \%(\mathrm{n}=1)$ in federal public institutions (Table 1). Of the respondents $92 \%(n=33)$ answered that there was presence of the physical therapist, and only $3 \%(n=3)$ answered that in the hospital where they work there was not. Regarding the workload required of the physical therapy professional in the emergency department, $83 \%(n=30)$ of respondents said it is 30 hours a week, $14 \%(n=5) 12$ hours a week and $3 \%(n=1) 24$ hours a week (Figure 2). 83\% $(n=30)$ of professionals claim that the workload is not restricted to patients requiring ventilatory support, while $17 \%(n=6)$ are restricted to those who require it.

Table 1. Socio-demographic characteristics of the physical therapists.

\begin{tabular}{|c|c|c|c|}
\hline Variables & & Answers $(\mathrm{n}=36)$ & Percentage \\
\hline \multirow{2}{*}{ Gender } & Male & 13 & $36.11 \%$ \\
\hline & Female & 23 & $63.88 \%$ \\
\hline \multirow{4}{*}{ Age } & $20-25$ years & 3 & $8.33 \%$ \\
\hline & 25 - 30 years & 13 & $36.11 \%$ \\
\hline & $30-35$ years & 10 & $27.77 \%$ \\
\hline & $35-45$ years & 10 & $27.77 \%$ \\
\hline \multirow{4}{*}{ Qualification time } & $1-5$ years & 15 & $41.66 \%$ \\
\hline & $6-10$ years & 8 & $22.22 \%$ \\
\hline & $11-16$ years & 11 & $30.55 \%$ \\
\hline & More than 16 years & 2 & $5.55 \%$ \\
\hline \multirow{5}{*}{ Title } & Graduation & 4 & $11.11 \%$ \\
\hline & Specialization & 28 & $77.77 \%$ \\
\hline & MBA and management & 1 & $2.77 \%$ \\
\hline & Masters & 2 & $5.55 \%$ \\
\hline & Doctorate & 1 & $2.77 \%$ \\
\hline \multirow{6}{*}{ Institution } & Private & 15 & $41.66 \%$ \\
\hline & Public Municipal & 13 & $36.11 \%$ \\
\hline & State Public & 5 & $13.88 \%$ \\
\hline & Federal Public & 1 & $2.77 \%$ \\
\hline & University Students & 2 & $5.55 \%$ \\
\hline & Military & 0 & $0 \%$ \\
\hline
\end{tabular}




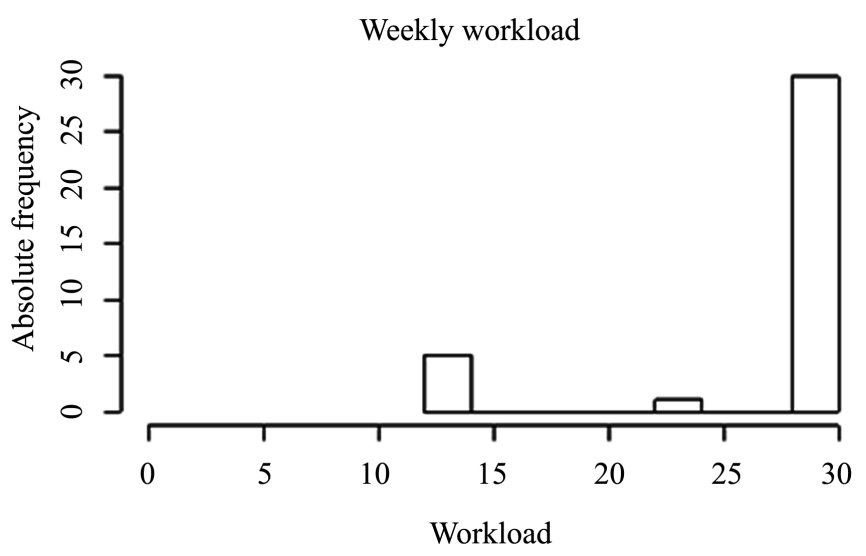

Figure 2. Histogram of weekly workload in hours.

The three most cited reasons for admission of these patients to the emergency room were respiratory failure (78\%), decreased level of consciousness (67\%), and stroke $(42 \%)$, and $56 \%(\mathrm{n}=20)$ stated that it was the Bilevel/BIPAP mode, $25 \%(n=9)$ said that it was the CPAP mode with flow generator and $14 \%(n=5)$ stated the micro-processed CPAP mode, however 53\% $(n=19)$ of the physiotherapists claimed that they did not use specific equipment to perform NIV (Figure 3$)$, therefore $33 \%(n=12)$ considered that there was a delay between the time of indication and the time of installation of this procedure (Figure 4).

The presence of a routine or technical coordination of physical therapy to discuss the evolution and the physical therapy service in the emergency room is not a reality in all hospitals, with $56 \%(\mathrm{n}=20)$ of the physical therapists interviewed citing the absence of this reality in the hospitals where they work (Figure $5)$.

About the average time of mechanical ventilation of patients, $47.22 \%$ replied to be in average from 1 to 2 days, $50 \%$ from 3 to 21 days, and $2.77 \%$ about being more than 21 days. Associated to this is the comparative analysis between the mean time of mechanical ventilation with the presence of an exclusive team in the emergency room (Figure 6).

Separating the data into two groups, with the first group having an exclusive team and the second group not having an exclusive team, a hypothesis test was performed to test if the variable Mean time of mechanical ventilation of the patients differs between the mentioned groups.

H0: Distribution of the variable mean time is the same between the groups and H1: Distribution of the variable mean time is not the same between the groups.

The result calculated by the test resulted in a p-value equal to 0.5188 . Since the result is higher than the significance level set at $5 \%$, we do not reject the null hypothesis (H0). Although the boxplot gave us the impression that the distributions between the groups were different, the test did not show us this evidence. Thus, there is no difference between groups for the variable mean duration of mechanical ventilation. 


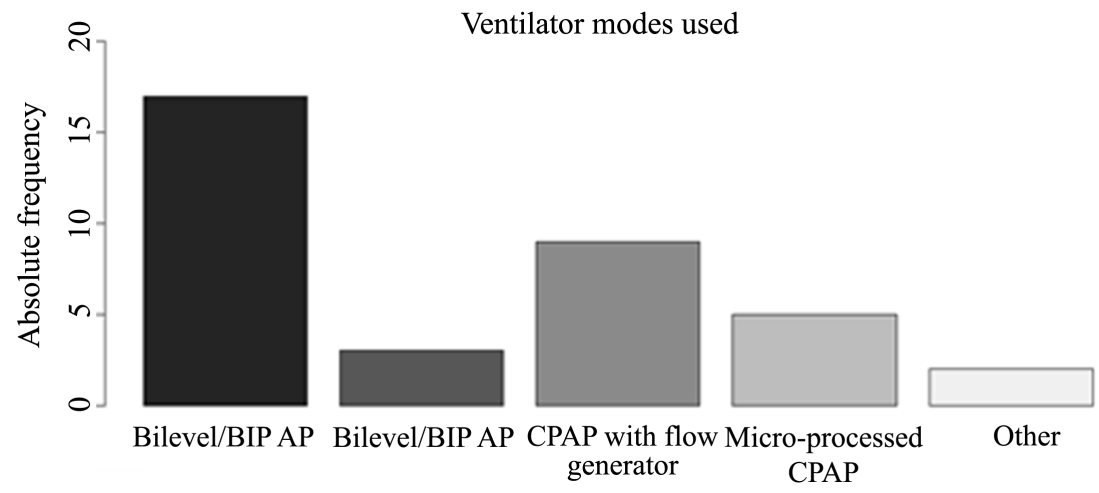

Figure 3. Most commonly used ventilatory modes in the emergency.

Delay in the time of NIV installation
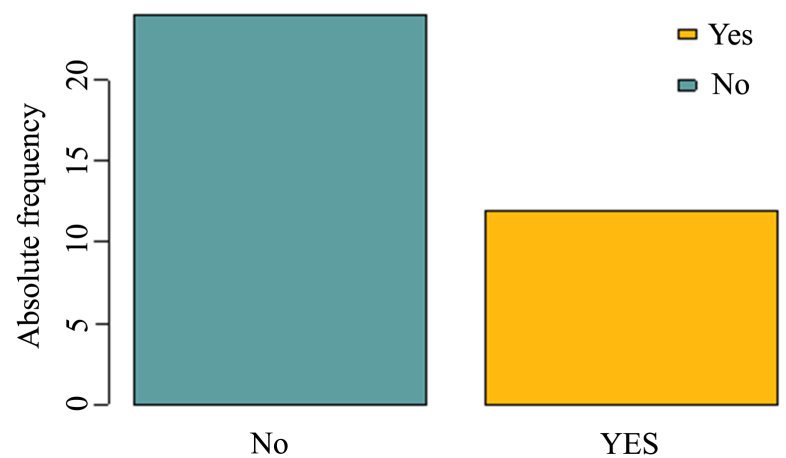

Figure 4. Noninvasive ventilation setup time delay.

Existence of a coordination in physiotherapy emergency
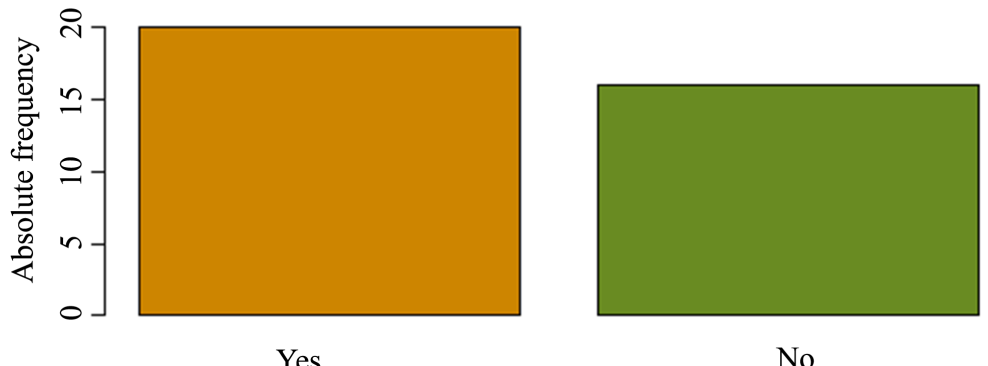

No

Figure 5. Existence of physical therapy coordination in the emergency.

Average mechanical ventilation time

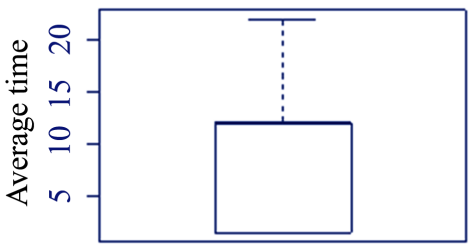

Average time per exclusive team

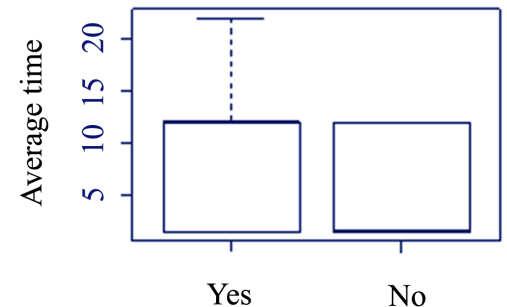

Figure 6. Mean time of mechanical ventilation in days and mean time by the existence of an exclusive team. 
In 2015, the American Heart Association (AHA) cited for the first time the inclusion of the physiotherapist as a component of the rapid response team [8], however, in Brazilian hospitals, his practice is still recent and restricted [13], with the main objective of fast and efficient care for patients with cardiorespiratory dysfunctions in the first hours [2], and currently it is observed that there is a great demand for this profile of patients who arrive at the emergency room, thus requiring a professional trained to use IMV, oxygen therapy and NIV [16].

In this study, it is possible to observe the insertion of the physical therapist in this field of work (92\%), either exclusively (25\%) or not (75\%). That physiotherapists in Australia and the United Kingdom are already inserted in emergency units due to the adequacy of the teams, and also verified a high rate of satisfaction with a $96 \%$ percentage of patients approached by these professionals [18], as well that verified a high degree of satisfaction, as well as reduced length of stay due to the more qualified approach and greater clarification on diagnosis and treatment [19].

They stated that the most common causes for intubation and admission to emergency units were altered state of consciousness $(38.3 \%)$, trauma $(23.2 \%)$, and respiratory failure (17.1\%) [20], while [6] observed that the highest incidences of admissions to emergency rooms were prechordialgia (18\%) and pneumonia (15\%), while [21] reported that they were sepsis of pulmonary focus (10.4\%) and stroke (10.4\%), corroborating our results, where the main reasons reported were respiratory failure (44\%), decreased level of consciousness $(36.1 \%)$ and stroke (13.8\%).

The longer the time of invasive mechanical ventilation, the greater the risks to the patient, the longer the length of stay and consequently the hospital expenses [20]. In this study, it was observed that $50 \%$ of professionals stated that the mean time of IMV is on average 3 to 21 days, while $12 \%$ reported a delay in the installation of noninvasive ventilation. However, good management of IMV and NIV in the emergency room may influence a better outcome throughout the patient's hospital stay. Given this length of stay on IMV in emergency units, the study [16], reports that the extensive duration in this sector justifies the deficit of beds in hospitals, causing patients to last longer than appropriate in these units.

\section{Answering the Fifth Question}

The use of breathing exercises by the physiotherapist, such as abbreviated expiration, which aims to prevent and/or treat respiratory complications in the emergency room, is considered important in the approach to the patient who is showing signs of ventilatory distress. In this sense, it is interesting the insertion of this professional in the urgency and emergency hospital sector in order to prevent and mitigate the occurrence of cardiorespiratory disorders [16].

\section{Final Considerations}

Despite the recent insertion of physical therapy in the emergency sector, physical therapists are increasingly entering this environment. In some hospitals it is al- 
ready possible to observe physical therapy restricted to the emergency room, with a work routine; however, some professionals are still moved from their sectors in hospitals to work in the emergency room.

There are several physiotherapeutic resources used in the emergency room, aiming at improving the patient's clinical condition and reducing the length of hospital stay.

In view of the above, the physical therapist has much to contribute in hospital emergency units and emergency care; however, he must be qualified for this task through the search for technical/scientific knowledge, thus contributing to the consolidation of this area of actuation.

\section{Answering the Fourth Question}

Therefore, for the professional advancement to be consolidated, new researches must be stimulated, higher education must serve as a base for the expansion of knowledge, promoting favorable clinical outcomes, reduction of hospitalization time, minimization of costs and impact on the patient's quality of life with physiotherapy performance in urgencies and emergencies.

\section{Conflicts of Interest}

This article presents no conflict of interest.

\section{References}

[1] Neves, C.A.B. (2006) Urgências e emergências em saúde: Perspectivas de profissionais e usuários. Cadernos de Saúde Pública, 22, 691-693. https://doi.org/10.1590/S0102-311X2006000300024

[2] Taquary, S.A.S., Ataíde, D.S. and Vitorino, P.V.O. (2013) Perfil clínico e atuação fisioterapêutica em pacientes atendidos na emergência pediátrica de um hospital público de Goiás. Fisioterapia em Pesquisa, 20, 262-267. https://doi.org/10.1590/S1809-29502013000300011

[3] Brasil (1999) Portaria ${ }^{\circ}$ 824, de 24 de junho de 1999. Institui a implantação de uma Política Nacional de Atenção Integral às Urgências. Ministério da Saúde, Brasília. https://www.ribeiraopreto.sp.gov.br/files/ssaude/pdf/ap-portaria-824-19990624.pdf

[4] Brasil (2002) Portaria $n^{\circ}$ 2048, de 5 de novembro de 2002. Reconhece a urgência e emergência como componente importante de assistência à saúde. Ministério da Saúde, Brasília.

[5] Brasil (2011) Portaria $n^{\circ}$ 1600, de 7 de julho de 2011. Reformula a Política Nacional de Atenção às Urgências e institui a Rede de Atençãoàs Urgências no Sistema Único de Saúde (SUS). Ministério da Saúde, Brasília. https://bvsms.saude.gov.br/bvs/saudelegis/gm/2011/prt1600_07_07_2011.html

[6] Ogawa, K.Y.L., Diniz, J.S., Frigeri, L.B. and Ferreira, C.A.S. (2009) Intervenção fisioterapêutica em emergências cardiorrespiratórias. O Mundo da Saúde, 33, 457-466. http://www.saocamilo-sp.br/pdf/mundo_saude/70/457a466.pdf https://doi.org/10.15343/0104-7809.20094457466

[7] Hess, D.R. (2013) Noninvasive Ventilation for Acute Respiratory Failure. Respiratory Care, 58, 950-972. http://rc.rcjournal.com/content/58/6/950 https://doi.org/10.4187/respcare.02319

[8] American Heart Association (2015) 2015 American Heart Association Guidelines 
Update for Cardiopulmonary Resuscitation and Emergency Cardiovascular Care. Circulation, 132, S313-S314.

[9] Minayo, M.C.S. and Deslandes, S.F. (2007) Análise diagnóstica da política nacional de saúde para redução de acidentes e violências. Fiocruz, Rio de Janeiro. https://doi.org/10.7476/9788575415412

[10] Brasil (2013) Portaria $n^{\circ} 342$, de 4 de março de 2013. Redefine as diretrizes para implantação do Componente Unidade de Pronto Atendimento (UPA 24h) em conformidade com a Política Nacional de Atenção às Urgências, e dispõe sobre incentivo financeiro de investimento para novas UPA 24h (UPA Nova) e UPA $24 \mathrm{~h}$ ampliadas (UPA Ampliada) e respectivo incentivo financeiro de custeio mensal. Ministério da Saúde, Brasília.

https://bvsms.saude.gov.br/bvs/saudelegis/gm/2013/prt0342_04_03_2013.html

[11] Conselho Federal de Fisioterapia e Terapia Ocupacional (2019) Resolução n ${ }^{\circ}$ 509, de 25 de julho de 2019. Reconhece a atuação do Fisioterapeuta na assistência à saúde nas Unidades de Emergência e Urgência. COFFITO, Brasília.

https://www.coffito.gov.br/nsite/?p=14984

[12] O’Dwyer, G., Matta, I.E.A. and Pepe, V.L.E. (2008) Avaliação dos serviços hospitalares de emergência do estado do Rio de Janeiro. Ciência \& Saúde Coletiva, 13, 1637-1648. https://doi.org/10.1590/S1413-81232008000500027

[13] Alves, M., Ramos, F.R.S. and Penna, C.M.M. (2005) O trabalho interdisciplinar: aproximações possíveis na visão de enfermeiras de uma unidade de emergência. Texto \& Contexto-Enfermagem, 14, 323-331. https://doi.org/10.1590/S0104-07072005000300002

[14] Fontelles, M.J., Simões, M.G., Farias, S.H. and Fontelles, R.G.S. (2009) Metodologia da pesquisa científica: Diretrizes para a elaboração de um protocolo de pesquisa. Revista Paraense de Medicina, 23, 1-8. http://files.bvs.br/upload/S/0101-5907/2009/v23n3/a1967.pdf

[15] Freire, M.C.M. and Pattussi, M.P. (2018) Tipos de estudos. In: Estrela, C., Ed., Metodologia Científica: Ciência, Ensino e Pesquisa, 3a ed., Artes Médicas, Porto Alegre, 109-127.

[16] Werle, R.W., Kutchak, F., Piccoli, A. and Rieder, M.M. (2013) Indicações para inserção do profissional fisioterapeuta em uma unidade de emergência. ASSOBRAFIR Ciência, 4, 33-41.

https://www.cpcrjournal.org/journal/assobrafir/article/5de02cd60e88253f794ce1d5

[17] Oliveira Junior, M.P., Azeredo, L.M. and Maia, G.G. (2017) Fisioterapia nas unidades de emergência e pronto atendimento. In: Martins, J.A., Reis, L.F. and Andrade, F.M.D., Eds., PROFISIO Programa de Atualização em Fisioterapia em Terapia intensiva adulto: Ciclo 8. Artmed Panamericana, Porto Alegre, 11-49.

[18] Kilner, E. and Sheppard, L. (2010) The "Lone Ranger": A Descriptive Study of Physiotherapy Practice in Australian Emergency Departments. Physiotherapy, 96, 248-256. https://doi.org/10.1016/j.physio.2010.01.002

[19] McClellan, C.M., Greenwood, R. and Benger, J.R. (2006) Effect of an Extended Scope Physiotherapy Service on Patient Satisfaction and the Outcome of Soft Tissue Injuries in an Adult Emergency Department. Emergency Medicine Journal, 23, 384-387. https://doi.org/10.1136/emj.2005.029231

[20] Angotti, L.B., Richards, J.B., Fisher, D.F., Sankoff, J.D., Seigel, T.A., Al Ashry, H.S. and Wilcox, S.R. (2017) Duration of Mechanical Ventilation in the Emergency Department. The Western Journal of Emergency Medicine, 18, 972-979.

https://doi.org/10.5811/westjem.2017.5.34099 
[21] Gonçalves, A.C.S. (2014) Perfil clínico dos pacientes atendido pelo serviço de fisioterapia na unidade de urgência e emergência de um hospital público de Minas Gerais. ASSOBRAFIR Ciência, 5, 55-62.

https://www.cpcrjournal.org/article/5de00c870e882578204ce1d5 